\title{
INSTABILITY OF A HIGH ALPINE ROCK RIDGE: THE LOWER ARÊTE DES COSMIQUES, MONT BLANC MASSIF, FRANCE
}

\author{
LUDOVIC RAVANEL ${ }^{1,2}$, PHILIP DELINE ${ }^{1}$, CHRISTOPHE LAMBIEL ${ }^{3}$ and CHRISTIAN VINCENT ${ }^{4}$ \\ ${ }^{1}$ EDYTEM Lab., Université de Savoie - CNRS, Le Bourget-du-Lac, France \\ ${ }^{2}$ TIK Lab., Swiss Federal Institute of Technology, Zurich, Switzerland \\ ${ }^{3}$ IGD, Université de Lausanne, Switzerland \\ ${ }^{4}$ LGGE, Université J. Fourier - CNRS, Saint Martin d'Hères, France
}

\begin{abstract}
Ravanel, L., Deline, P., Lambiel, C. and Vincent C., 2013. Instability of a high alpine rock ridge: the lower arête des Cosmiques, Mont Blanc massif, France. Geografiska Annaler: Series A, Physical Geography, 95, 51-66. DoI: $10.1111 /$ geoa. 12000
\end{abstract}

\begin{abstract}
Rockfalls are dominant in the rock slopes and rock ridge morphodynamics in high mountain areas and endanger people who pass along or stay there, as well as infrastructure that host them (cable cars, refuges). Risks are probably greater now because of fast permafrost degradation and regression of surface ice, two consequences of the atmospheric warming of the last decades. These two commonly associated factors are involved in the instability of rock slopes by modifying the mechanical behaviour of often ice-filled rock fractures and the mechanical constraints in the rock masses. This paper examines over 15 years the instability of the lower Arête des Cosmiques on the French side of the Mont Blanc massif. Its vulnerability is due to the presence of a high-capacity refuge on its top (3613 $\mathrm{m}$ a.s.1.). In 1998 , a part of the refuge was left without support when a collapse of $600 \mathrm{~m}^{3}$ occurred immediately below it. Since this date, reinforcement work has been carried out in this area, but the whole ridge has been affected by around 15 relatively shallow rockfalls. Through a multidisciplinary approach, this article assesses the role of the cryospheric factors in the triggering of these rockfalls.
\end{abstract}

Key words: high alpine rock slopes, rockfalls, permafrost, glacier shrinkage, hazards, mountain infrastructure, Mont Blanc massif

\section{Introduction}

Glacier retreat and permafrost degradation are currently and progressively more thought to explain the increasing instability of rock slopes and rock ridges in high mountain environments. The hot or even blistering summers (2003) with numerous rockfalls experienced over the last two decades in the Alps have indeed contributed to test and/or strengthen the hypothesis of a strong correlation between rockfalls and global warming through these two cryospheric factors (Gruber et al. 2004).

Permafrost is defined as any lithosphere materials that permanently remain at or below $0^{\circ} \mathrm{C}$ (for at least two consecutive years). Unlike glaciers that are ice masses visible at the surface, permafrost as a thermal state is invisible, inasmuch as it is a subsurface phenomenon and does not necessarily contain ice. However, especially when it is connected to glaciated areas or recently deglaciated areas, permafrost may contain - in rock discontinuities in the case of rock slope permafrost - ice as well as fillings of boulders, gravel, sand and rock particles, and also liquid water. This ice can provide a stabilizing role by increasing the shear and tensile strength of discontinuities (Davies et al. 2000; Krautblatter 2009) and by reducing the hydraulic permeability of the rock masses involved. The current global warming, intensifying the heat exchange between the atmosphere and permafrost, can induce the degradation of the latter and thus a loss of strength of discontinuities - in various ways (sequential or concurrent; Gruber and Haeberli 2007): heating of the subsurface layer; deepening of the active layer (i.e. the superficial layer that thaws each summer); warming of the permafrost body; formation of thawing corridors along major discontinuities due to water/air circulation; and rise in altitude of isotherms and thus of the lower permafrost limit. The retreat of glaciers can lead to a loss of support at the base of rock slopes or to a decompression due to the variation of internal stresses in the rock: the stress release can 
open cracks and thus destabilize rock masses by gravity (Cossart et al. 2008). In addition, newly exposed rock slopes following glacier retreat may be subject to previously never occurred phases of warming, accelerating permafrost degradation. Since the end of the Little Ice Age, some alpine glaciers have lost up to $300 \mathrm{~m}$ of ice or more in their marginal areas (Paul and Haeberli 2008), and probably a few tens of meters in the lower area of their accumulation basin.

Rockfalls from recently deglaciated and/or thawing areas may have very important economic and social implications for high mountain infrastructure (Haeberli 1992; Haeberli et al. 1997; Harris et al. 2001; Arenson et al. 2009; Bommer et al. 2010; Kenner et al. 2011) and be a fatal hazard for mountaineers. At high mountain sites characterized by infrastructure that can be affected by rockfalls, the monitoring of rock slopes, permafrost and glaciers is thus an essential element for the sustainability of the infrastructure and for the management of risks (Bommer et al. 2010).

Our article focuses on a particularly active area of the Mont Blanc massif, the lower Arête des Cosmiques ( $L A C)$, on which is located the very popular Refuge des Cosmiques (3613 m a.s.1.). Since 1998, the date of a rockfall that unsettled a part of the refuge and required major stabilizing work, observations made in particular by the hut keepers allowed rockfalls, especially on the SE face of the LAC, to be identified. Since 2009, this face is surveyed each year by terrestrial laser scanning to obtain high-resolution 3D models whose diachronic comparison gives precise measurements of the evolution of the rock slope. Furthermore, rock temperature measurements at the LAC and the close Aiguille du Midi (3842 m a.s.l.), and observations of the evolution of the underlying Glacier du Géant should enable the origin of the strong dynamics of this highly vulnerable area to be better understood.

\section{Study site}

\section{The Mont Blanc massif}

The Mont Blanc massif, oriented SW-NE, has an area of approximately $550 \mathrm{~km}^{2}$ and its highest point is at $4810 \mathrm{~m}$ a.s.l. Bordered by the deep Valley of Chamonix at the NW, Val Veny at the SE, and Val Ferret at the east, it is characterized by an extraordinary combination of peaks and ridges, with glaciers covering about $30 \%$ of its surface. Many of its granitic, fractured faces and summits stand well above $3000 \mathrm{~m}$ a.s.l.: the drainage divide between Rhône and Pô basins forms a 35-km-long crest line which is continuously above $3300 \mathrm{~m}$ and locally exceeds $4000 \mathrm{~m}$ a.s.l.

The Mont Blanc is mainly a granitic batholith formed during the Hercynian orogeny by granite intrusion in the gneissic basement (micaschists and gneiss). The Mont Blanc summit is on the contact of these two units. The granite changes from an intrusive position in gneiss in the SW to a tectonic contact in the NE. Tilted towards the NW, the massif is cut into panels by large subvertical Variscan, recurrent faults (north-south), and alpine faults (N40-N60 $\left.{ }^{\circ} \mathrm{E}\right)$ with mylonitized zones (shear zones). The Mont Blanc granite has a very coarsegrained texture, with facies varying from microgranite to porphyroidic granite. Multiple tectonic phases have broken up the rock with multiple direction planes that may overlap. Finally, the combination of past and present glaciations, steep and fractured rock walls, and strong relative relief results in high-magnitude morphodynamics.

\section{The lower Arête des Cosmiques}

The LAC is located at $600-1000 \mathrm{~m} \mathrm{SSW}$ of the Aiguille du Midi (3842 m a.s.1.), developing horizontally over around $400 \mathrm{~m}$ (Fig. 1). Its slopes differ strongly with respect to the elevation range (350 $\mathrm{m}$ for the NW face and $50 \mathrm{~m}$ for the SE face, on average) and structure with no particular structure visible in the NW face and a more massive but much fractured SE face.

At the SE face several sets of discontinuities can be observed. The main one corresponds to NW-SE-oriented faults. They determine the position of the main couloirs. In the immediate vicinity of these faults, the rock is 'crushed' in small blocks (shear zones). The general angle of the slope is approximately $50^{\circ}$ and allows - at least during part of the year - the presence of a protective snow cover, especially in the couloirs that separate steeper spurs.

Besides these faults, two other sets of discontinuities are developing. A first set corresponds to a fracturing parallel to the faults. This fracturing is dominant over the SW half of the face. In the NE half, it is replaced by a set oriented WSWENE, which determines the meso-aspects of the rock slope. The rock mass here is cut into panels that are parallel to the slope (dip slope). This is particularly true for those upon which are built the foundations of the refuge. Halfway between 


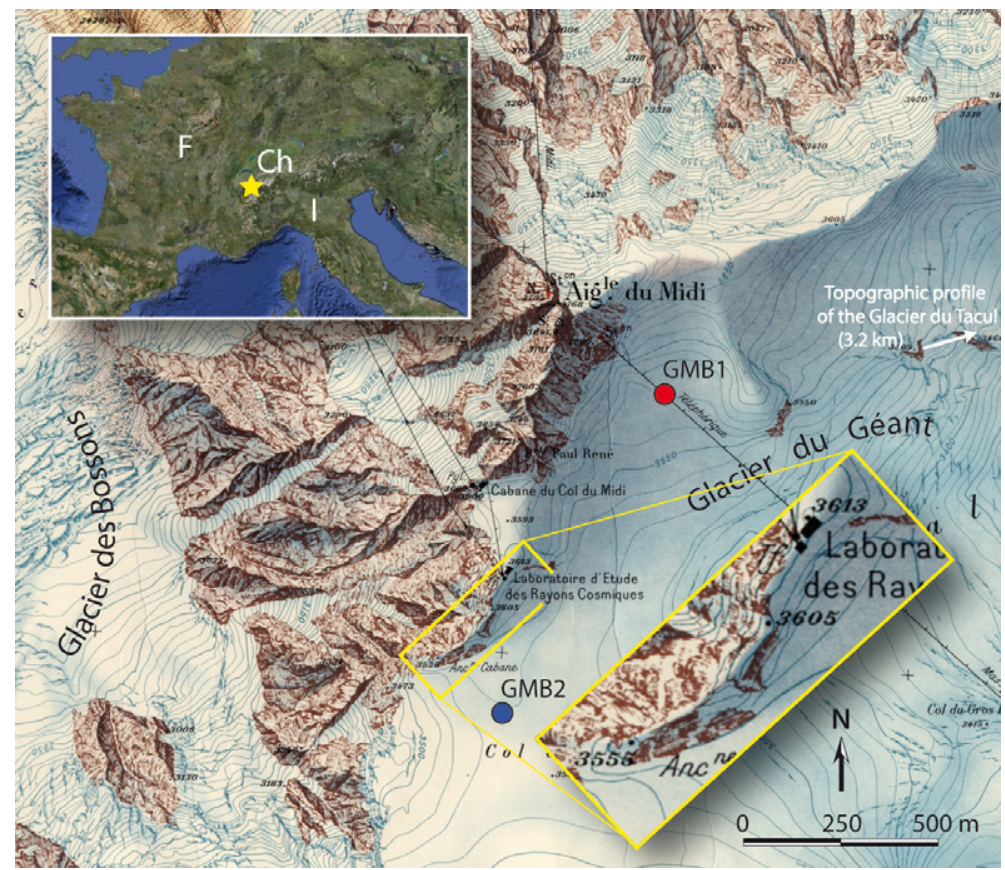

Fig. 1. The Aiguille du Midi area (3842 m a.s.1.; Mont Blanc massif, western Alps). The ridge that develops south (the upper Arête des Cosmiques) continues beyond a snowy pass by a ridge oriented NE-SE: the LAC (box). Extract of the sheet Mont Blanc $n^{\circ} 1$ Nord - Aiguille du Midi (IGN, 1952, scale: 1:10 000, contour interval: 10 m; Copyright: IGN). The Laboratory of Cosmic Rays is now replaced by the Refuge des Cosmiques. GMB1 and GMB2: stakes for the glacial mass balance measurement. The construction noted 'Ancienne cabane' no longer exists.

the refuge and the southern limit of the LAC, the two sets of discontinuities have a similar development: rock is thus not cut into panels any more, but in large blocks, especially as a fourth much more heterogeneous set cuts the rock mass more or less horizontally.

The main feature of the LAC is to host the Refuge des Cosmiques (3613 m a.s.l.). A first refuge had been built in 1943 in order to study cosmic rays; it suffered from a fire in the 1980s. Built between 1989 and 1991, the new refuge with a very modern architecture combining metal, wood and glass has a capacity of over 140 beds. The foundations of the refuge are essentially a few dozen cubic metres of concrete poured by helicopter (multi-pod and concrete massif structure on the excavation surface). Accessible from the Aiguille du Midi, the refuge is held open for 8 months of the year and is the starting point of the famous Vallee Blanche ski descent and of numerous ascents (second main route to the Mont Blanc summit for example), which explains its high activity (10 000 to 12000 nights per year). The NE end of the LAC hosts a small shelter made of wood (the Abri Perroux), located $70 \mathrm{~m}$ east of the refuge.

\section{Methods \\ Rockfall identification: direct observations and terrestrial laser scanning}

In order to better understand the trigger of rockfalls in high mountain rock slopes, a structured network of observers (mountain guides, refuge keepers) combined with direct field observations was developed in the Mont Blanc massif (Ravanel et al. 2010a). On the French side of the massif, rockfalls started to be precisely documented in 2005. In the case of the LAC, the presence of refuge keepers attentive to the mountain evolution has yielded a quasi-complete corpus of rockfalls since 2003. Prior to this date, a rockfall in the hot summer of 1998 had already attracted the attention of keepers and risk managers in Chamonix. It affected the slope immediately below the refuge, requiring closure of the refuge and important consolidation work. These observations were then completed in 
the field by high-resolution topographic measurements in order to characterize the affected areas and to compute the fallen volumes.

Those topographic measurements have been carried out from the glacier surface using a terrestrial laser scanner (TLS) installed on a tripod anchored deep in the snow, ensuring a satisfactory instrument stability over the whole time needed to complete a scan (a few tens of minutes). The whole LAC was scanned from two positions located 80-100 m SE from the LAC in order to reduce masks due to the rough topography (spurs and couloirs). TLS is an active acquisition device that emits electromagnetic energy in the form of laser beams and records back the amount of energy that is reflected by the object being scanned. The high degree of accuracy in the measurement of the time of flight and of the angle attitude of each pulse provides high-resolution point clouds very quickly (Lichti et al. 2002; Oppikofer et al. 2008; Abellan et al. 2009; Ravanel et al. 2010b). Our first TLS campaign in the Cosmiques area was carried out on 4 October 2009. Two others were carried out in the following two years (7 October 2010; 15 September 2011). Measurement campaigns are conducted at the end of the summer, when ice/snow cover is reduced, the geomorphic activity peak exceeded, and the weather quite stable. The device used was an Optech ILRIS 3D (wavelength: $1500 \mathrm{~nm}$; acquisition speed: 2000 points per second; effective range: $600 \mathrm{~m}$ ). According to the manufacturer, the acquisition accuracy of a point at $100 \mathrm{~m}$ is $7 \mathrm{~mm}$ in distance (distance between the TLS station and the measured point on the Y-axis of a coordinate system specific to the scanner; the Y-axis is generally perpendicular to the scanned surface) and $8 \mathrm{~mm}$ in position (on the $\mathrm{X}$ - and Z-axis). Initialization and setup of the scanner are controlled by a driver installed on a field computer. After the determination of shooting windows and the point spacing, the acquisition is carried out automatically with a resulting resolution of approximately 50 . The obtained point clouds are registered in the software InnovMetric PolyWorks to get a full single high-resolution 3D model of the rockwall (a primary alignment with $n$ pairs of corresponding points is then improved by best fit; Rabatel et al. 2008). Since the purpose of the TLS here is to identify/quantify rock detachments and not to generate a geomechanical model, 3D models have not been referenced in a geographic coordinates system. The comparison of 3D models allows morphological changes to be measured. The result of this comparison is a difference map where each point of the 3D model 'data' is coloured depending on its distance from the nearest point on the 3D model 'reference'. The operator can then identify rockfalls once the differences resulting from changes in ice/snow cover - and eventually shifts in measuring stations - have been interpreted as such (see Fig. 3b). Then, the volume of the identified rockfalls can be computed. The total uncertainty can be estimated by the quadratic sum of the different independent errors in acquisition and processing (Rabatel et al. 2008). These include instrumental errors, environmental errors (changes in light propagation due to changes in temperature, pressure, wind and humidity), errors in the construction of the 3D models (errors of registration), and errors in the overlapping of 3D models when two successive models are compared. Avoiding point interpolation here - the derivation of a highresolution triangulated irregular network model is not necessary - the maximum total uncertainty is around $54 \mathrm{~mm}$ on the Y-axis, much less on the others. To overcome this uncertainty, differences less than $100 \mathrm{~mm}$ between two models are excluded from interpretation.

\section{Rock temperature measurement}

The surface temperature of a rock slope is controlled in particular by the mean annual air temperature (MAAT) partly depending on the altitude, the potential direct incoming solar radiation (PSR) received by the slope, depending on the topography (aspect, slope angle), and the snow cover. The MAAT can be inferred from local weather station data and/or regional climate models by applying an altitudinal gradient; the PSR is calculated with a GIS. Combining these two parameters with a digital elevation model (DEM), the mean annual ground surface temperature (MAGST) of the Mont Blanc massif can be modelled. The possible presence of permafrost at the Cosmiques area has thus been first estimated from the MAGST modelled with the energy balance model TEBAL (Gruber et al. 2004; Ravanel et al. 2010a).

For continuous monitoring of the thermal regime of the SE and NW faces of the LAC, two Geoprecision M-Log6 sensors (resolution: $0.01^{\circ} \mathrm{C}$, accuracy: $\pm 0.05^{\circ} \mathrm{C}$ ) were installed in the rock in May 2011. On the SE face, the sensor was installed $15 \mathrm{~m}$ below the refuge (3598 $\mathrm{m}$ a.s.1.), in the 1998 scar. On the NW face, the sensor was installed $10 \mathrm{~m}$ below the terrace of the refuge (3603 $\mathrm{m}$ a.s.1.), in a 
massive slab. These sensors are composed of three thermistors positioned in shallow boreholes in massive bedrock at 3,30 and $55 \mathrm{~cm}$ deep. The temperature was recorded every $6 \mathrm{~h}$.

The same sensors have also been located in the nearby Piton central of the Aiguille du Midi since 2005. In addition to these subsurface sensors, three $11 \mathrm{~m}$ deep boreholes have been drilled in 2009 at the Aiguille du Midi, normal to the surface of the vertical NW face (3738 $\mathrm{m}$ a.s.1.) in a very massive rock, the $\mathrm{SE}$ face (3745 $\mathrm{m}$ a.s.1.) on a $55^{\circ}$ slope that is more fractured and temporarily covered by snow, and the NE face ( $3753 \mathrm{~m}$ a.s.1.) on a $65^{\circ}$ slope also covered by snow for part of the year. In each borehole, a chain of 15 thermistors (Stump YSI 44031; resolution: $0.1^{\circ} \mathrm{C}$, accuracy: $\pm 0.1^{\circ} \mathrm{C}$ ) measures the temperature every $3 \mathrm{~h}$ at depths between $30 \mathrm{~cm}$ and $10 \mathrm{~m}$. These thermistors are useful for comparison with the LAC data and allow the active layer depth to be determined, as they are deeper than those on the LAC.

\section{Characterization of glacier changes}

The evolution of glaciers is easily discernible at the tongue of alpine glaciers which are currently losing up to several metres in thickness each year. However, accumulation zones are - even though to a much lesser extent - also affected by sometimes quite marked changes. There are less data concerning accumulation zones than ablation zones. The glacier changes were here quantitatively and qualitatively estimated by the following.

1. Point measurements of glacier mass balance. In the upper basin of the Glacier du Géant, mass balance studies have been performed at individual points (GMB1 and GMB2 on Fig. 1) since 1994, currently under the GlacioClim observation service. Glacier mass balance (Bamber and Payne, 2004) is the difference between the amount of snow accumulated during the winter and the amount of snow/ice removed by melting during the warmer period. To determine the mass balance in the accumulation zone, snowpack depth is measured by probing (more rarely snow pits or crevasse stratigraphy).

2. Topographic profile. There are no data concerning the annual evolution of the level of the surface of the Glacier du Géant, even though it largely depends on the mass balance. The closest available data are those of the Glacier du
Tacul, formed by the confluence of the Glaciers du Géant (including the part called Vallée Blanche), de l'Envers du Plan, and des Périades. A topographic profile is surveyed each year at $2230 \mathrm{~m}$ a.s.l. (ablation zone), $4.7 \mathrm{~km} \mathrm{NE}$ of the LAC.

3. Assessments from topographic maps and photographs. Because of the lack of quantitative data out of a study based on the comparison of satellite images for the period 1979-2003 (Berthier 2005), changes in the glacier/ice surface can be qualitatively assessed from available IGN topographic maps, photographs, and observations by mountain guides. Different generations of detailed maps exist, typically surveyed in late summer when the snow cover is minimal, giving information on the effective glacier extent. To be of any use for the determination of glacier extent, photographs must have been taken in late summer, before the first important snow falls.

\section{Evolution of the LAC area \\ Rockfalls between 1998 and 2011}

We have no evidence of instability in the early years of the refuge (construction finalised in 1991). The first important collapse occurred on 22 August 1998 in the SE face, immediately below the refuge $\left(600 \mathrm{~m}^{3}\right.$; see below). No evidence of instability was collected for the following 5 years. Observations have been completed since 2003 for the SE face (Table 1; Fig. 2); observation of the NW face is much more difficult. During the 2003 summer heatwave, a rockfall $\left(140 \mathrm{~m}^{3}\right)$ occurred $100 \mathrm{~m} \mathrm{SW}$ of the refuge in a highly fractured area. A few hours after the collapse, 'dirty ice' (i.e. ice loaded with fine rock elements: separated minerals, sand and gravel) was observed in the scar by climbers. The affected area has remained very active until today. In 2004, almost simultaneously with the detachment of a boulder of around $60 \mathrm{~m}^{3}$ on the NW face (2004c), two rockfalls occurred on the SE face. One mobilized a rock volume of $200 \mathrm{~m}^{3}$ (2004a) in the immediate vicinity of the scar of 2003, whereas the second one (2004b, $20 \mathrm{~m}^{3}$ ) reshaped the SW margin of the 1998 scar. Ice was observed in the scar of the first one, and water flows in the second one. A new deposit formed on the Glacier du Géant due to a rockfall of $85 \mathrm{~m}^{3}$ that occurred on 29 July 2006 (at the end of the hot first half of summer) on the crest line, just above the 2003 scar. Ice persisted in the scar for several days. Another rockfall detached 


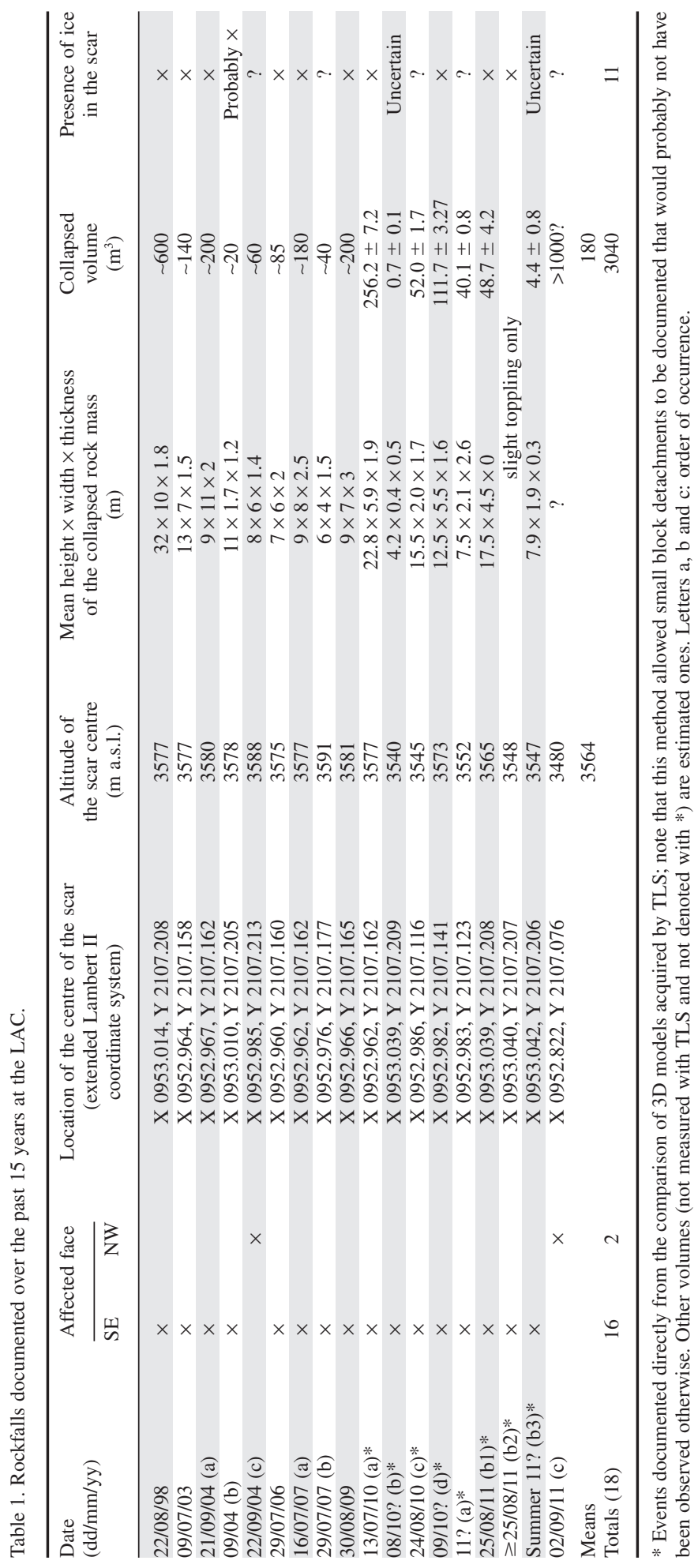



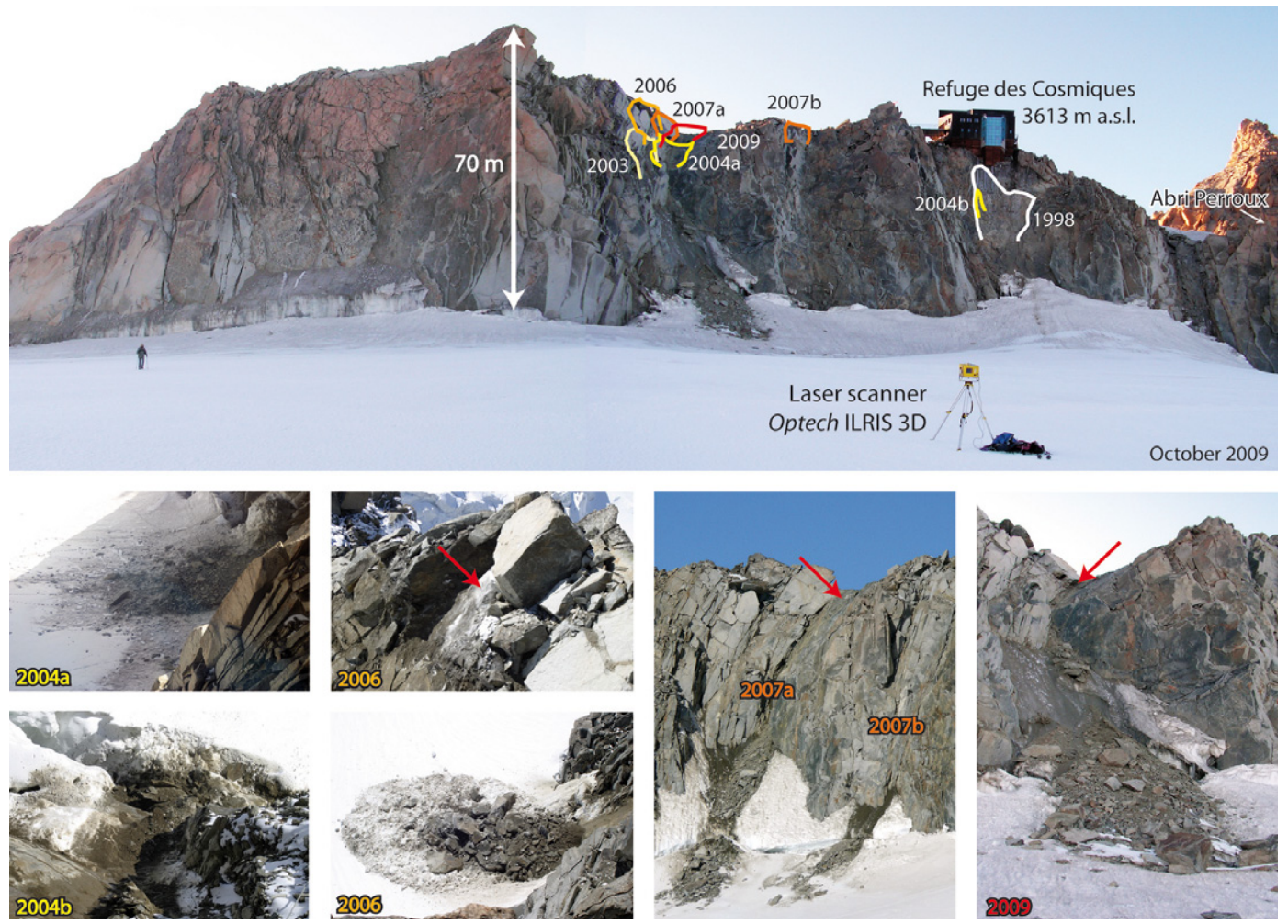

Fig. 2. The rockfalls on the SE face of the LAC reported before the beginning of use of the TLS method in October 2009 (photos 2004 and 2006: A. Sage). 2004a: deposit seen from the refuge; 2004b: deposit seen from the refuge; 2006 (top): scar seen from the crest; 2006 (bottom): deposit seen from the crest; 2007: scars and deposits seen from the glacier; 2009: scar and deposit seen from the glacier. Ice (red arrows) was observed in many scars; except in 2006, it was generally dirty ice (i.e. mixed with fine particles, sand and gravel), sometimes thick ( $20-25 \mathrm{~cm}$ in 1998).

from the same area on 16 July 2007 (2007a, $180 \mathrm{~m}^{3}$ ), reshaping the crest line; a mass of dirty ice was present in its scar. Two weeks later, a rockfall $\left(2007 \mathrm{~b}, 40 \mathrm{~m}^{3}\right)$ affected the ridge again, midway between the refuge and the highly unstable area. No significant destabilization occurred until 30 August 2009 in this highly unstable area, when a rockfall $\left(200 \mathrm{~m}^{3}\right)$ detached just above 2004a, mobilizing blocks that formed the crest of the LAC; dirty ice was still present in the scar several days later.

Between 2009 and 2011, three TLS surveys of the SE face were realized. These sets of data allow two comparisons of 3D models. The first comparison was used to assess the evolution of the SE face between October 2009 and October 2010 (Fig. 3a; Table 1). It shows two unstable areas. The first, fairly recurrent, was the most active area between 2003 and 2009, with five rockfalls. Three new ones affected it in summer 2010: a fractured block of $256.2 \mathrm{~m}^{3}$ (2010a) detached on 13 July 2010, a few metres below the ridge, and deposited on the Glacier du Géant; the outer face of this block was mostly made up of the 2006 scar. A few metres above the glacier, a block of $0.7 \mathrm{~m}^{3}(2010 \mathrm{~b})$ and a pile of blocks of $52 \mathrm{~m}^{3}$ (2010c) previously embedded in ice were destabilized at the end of August. The second unstable area recognized during the period is the main couloir between the refuge and the Abri Perroux (2010d), where no significant instability had been observed previously. A minimal volume of $111.7 \mathrm{~m}^{3}$ of rock (2010d) detached in early September 2010 in the lower part of the couloir and was deposited at the bottom of the couloir. Because it protected the glacier surface from ablation, the glacier at the foot of the couloir was higher by $1.7-2.5 \mathrm{~m}$ in 2010 compared with 2009 , whereas it was lower everywhere else.

Many differences result from the second comparison between the models of October 2010 and September 2011 (Fig. 3b; Table 1), but most of 

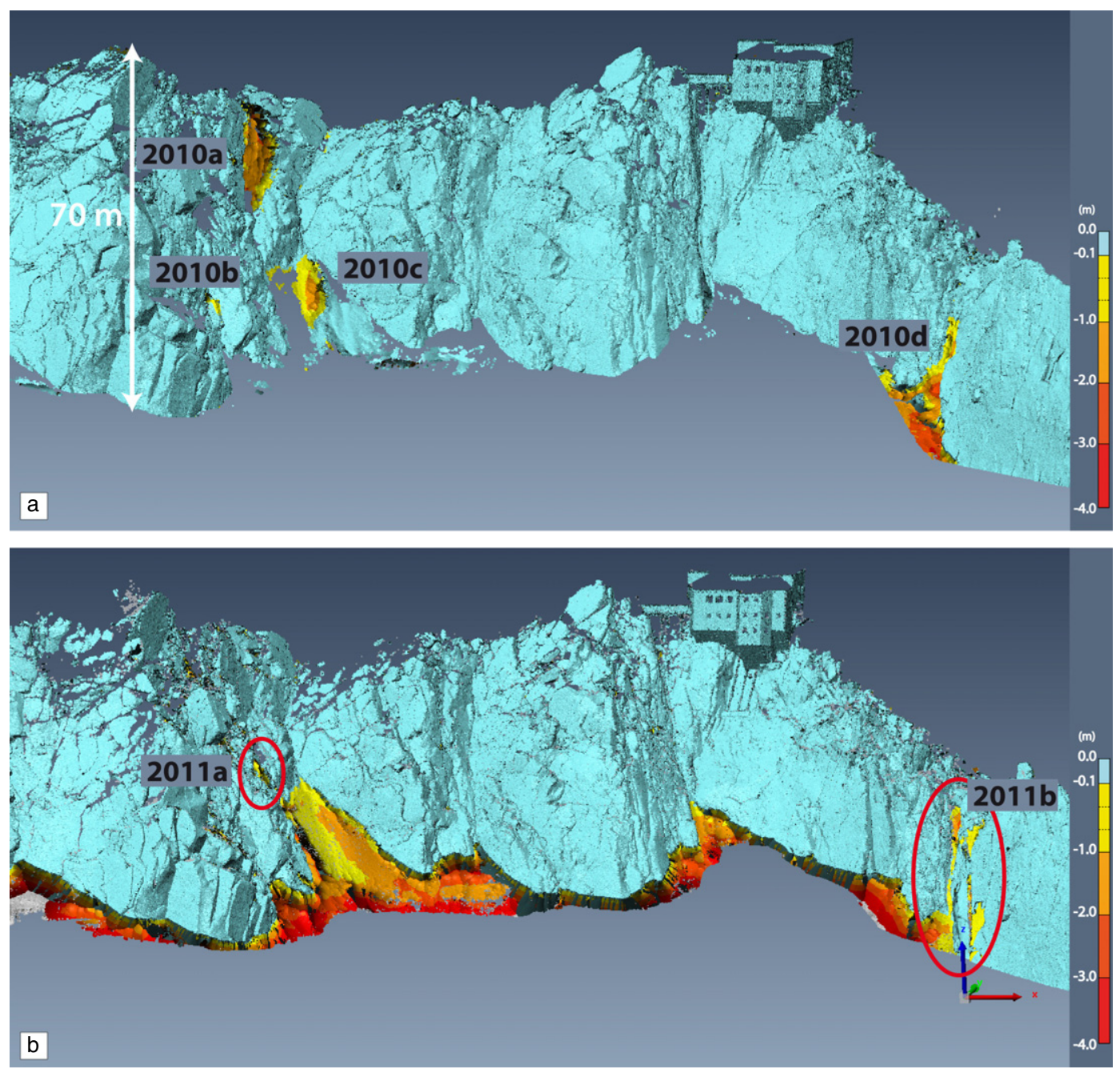

Fig. 3. Comparison of the 3D models of the SE face of the LAC. (a) Comparison of October 2009 and October 2010, and position of the four identified rock detachments between the two dates. (b) Comparison of October 2010 and September 2011, and position of the two identified rock detachments (or series of detachments) between the two dates. Particular attention should be paid to the variation of snow cover which clearly appears at the base of the slope. Scale on the right is in $\mathrm{m}$.

them are due to a lower snow level in 2011 than in 2010. This was not the case for the first comparison because snow which fell in September 2010 'stuck' on the foot of the rock slope creating a positive change compared with 2009, although the glacier surface was lower. Two unstable areas were identified for this period. A massive block of $40.1 \mathrm{~m}^{3}$ (2011a) detached about $10 \mathrm{~m}$ downstream from the most active area; the date of the occurrence is unknown. A second unstable area is the main couloir (Fig. 4) located east of the refuge, already active between 2009 and 2010. In its lower part (2011b) three events occurred separated in time: at the bottom of the couloir, the instability documented in 2010 continued on 25 August 2011 with the deepening of the couloir over a height of over $17 \mathrm{~m}$, mobilizing $48.7 \mathrm{~m}^{3}$ of highly fractured rock material (2011b1); on the left bank of the couloir, a column $(2011 \mathrm{~b} 2 ; 19 \times 2.8 \times 3.5 \mathrm{~m})$ slightly tilted (rotation) towards the centre of the couloir, likely between 25 August and 15 September; the top of this massive block moved on $1.15 \mathrm{~m}$; a third detachment in this area (2011b3; undated) mobilized a thin slab of $4.4 \mathrm{~m}^{3}$. 


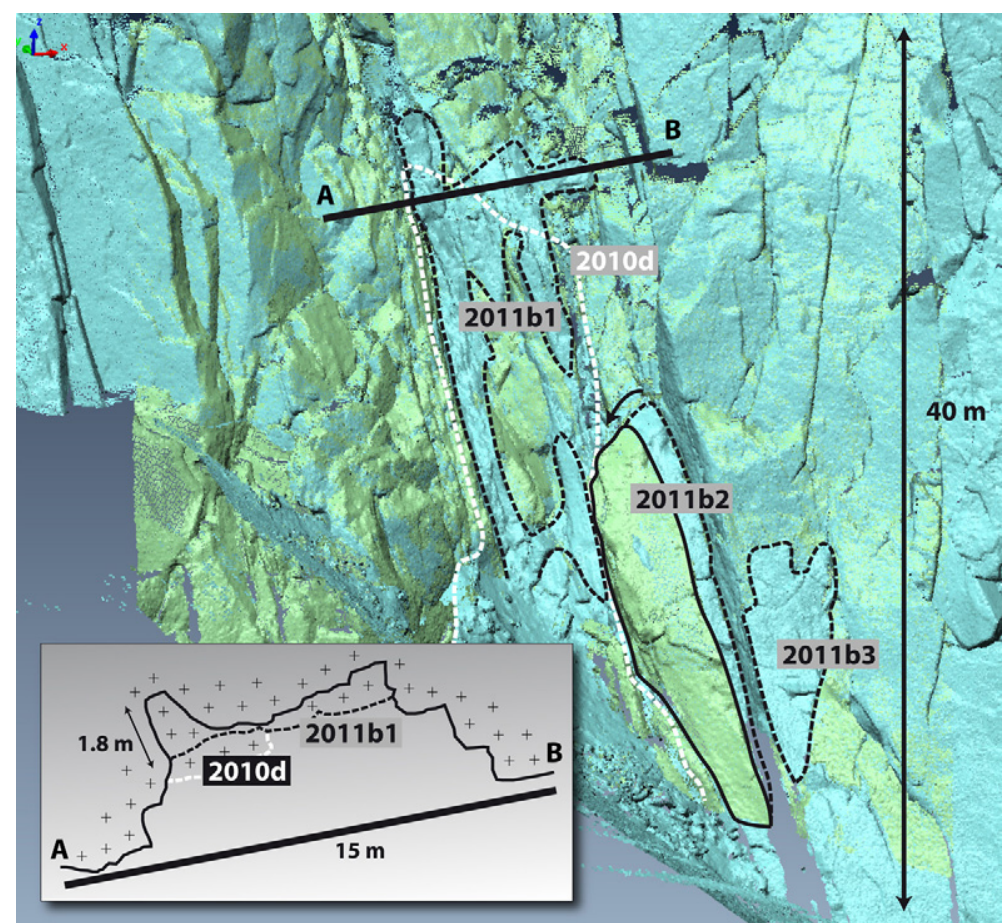

Fig. 4. Detail of instabilities that occurred in the lower part of the couloir located east of the refuge during summers 2010 and 2011. Sub-horizontal profile $\mathrm{AB}$ shows the progressive deepening of the couloir.

Finally, the refuge keepers reported a rockfall (probably $>1000 \mathrm{~m}^{3}$ ) on the NW face, not surveyed by TLS, of the LAC during the night 24-25 August 2011. After the main collapse, block falls were heard for more than $10 \mathrm{~min}$.

\section{The rockfall of 1998, implications and management}

On the basis of the noise, a first rockfall occurred on the evening of 21 August 1998. It was first supposed to be a huge ice fall from the close north face of the Mont Blanc du Tacul (4248 m a.s.1.). Early in the morning on 22 August, a second, larger rockfall occurred. This event affected the SE face of the LAC immediately below the refuge. The refuge was almost empty on this date due to hot and unstable weather which was not conducive to climbing. The staff were immediately evacuated, and a by-law prohibited access to the refuge.

The volume of rock $\left(600 \mathrm{~m}^{3}\right)$ involved in a planar slide thanks to a discontinuity $55^{\circ} \mathrm{E}-56^{\circ} \mathrm{SE}$ corresponded mainly to a rather fractured slab, $32 \mathrm{~m}$ high, $10 \mathrm{~m}$ wide and $1.8 \mathrm{~m}$ thick on average
(Fig. 5). A part of the steel structure (several I profile beams, $I P B)$ supporting the 'crystal' of the refuge (i.e. the prominent part of the SE glass façade) was built on this slab. After the rockfall, this part was only supported by the cohesion of the refuge provided by the original metal/wood structure, justifying the by-law.

Stabilization work of the refuge has been carried out in two steps. Soon after the rockfall and during the fall of 1998, a first step ensured the integrity of the building before winter. A prefectural order prohibited the reopening of the refuge before the completion of the second phase of work. Carried out mainly during April 1999, this step consisted of an anchoring of the rockwall, the establishment of a concrete settlement, and a re-seating of the metal structure of the 'crystal' on this settlement. The anchoring consists of steel anchors placed in holes drilled through the entire mass considered as unstable, penetrating into more stable rock to transfer forces with an acceptable degree of safety. Anchoring was made over a height of $20 \mathrm{~m}$ below the refuge, in the form of 120 passive anchors sealed along their entire 

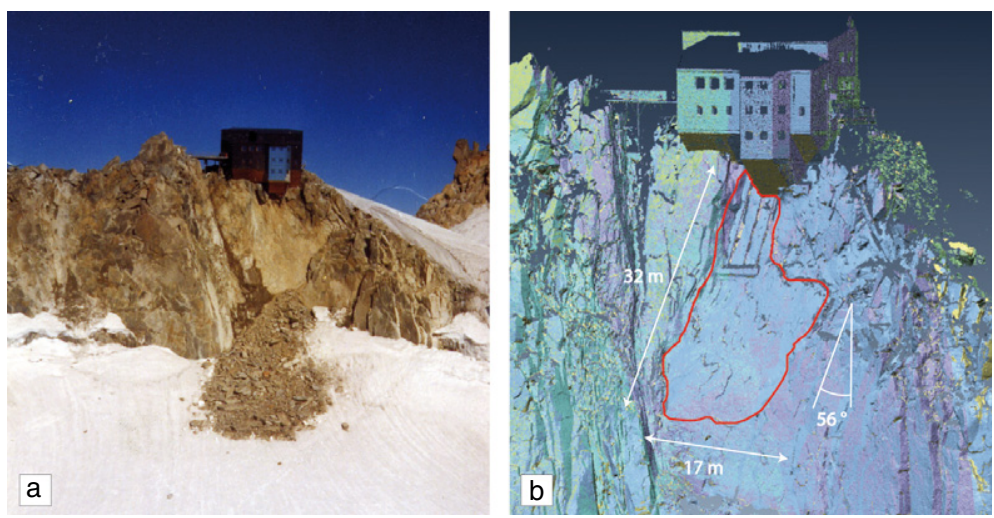

Fig. 5. The Cosmiques rockfall of August 1998. (a) Ccar and deposit of the rockfall $\left(600 \mathrm{~m}^{3}\right)$; a portion of the refuge became unsettled (photo: A. Sage). (b) Characteristics of the affected area on the high-resolution 3D model of the SE face of the LAC acquired by TLS in October 2009; the average thickness of the slab which rested on a thick layer of ice mixed with rock debris was $\sim 1.8 \mathrm{~m}$.

length $(2-6 \mathrm{~m})$, inducing additional shear resistance; 78 were placed directly into the scar. At a height of $10 \mathrm{~m}$ below the refuge, a protruding concrete reinforcement gave a greater cohesion to this much fractured area; 28 anchors provide stability on the east bank of the scar, and 14 on the west. A $6 \mathrm{~m}$ long horizontal concrete settlement was performed $10 \mathrm{~m}$ below the 'crystal'; this rigid support ensures the blocking of rock masses, and provides a foundation for the three IPBs which now support the 'crystal' (see Fig. 8a).

\section{Thermal state of the rock ridge}

MAGST was modelled with TEBAL for the period 1982-2002, using meteorological data from Corvatsch and Jungfraujoch stations (Switzerland) and not the Aiguille du Midi station, where air temperature has been measured continuously only since February 2007. According to this model, MAGST of the rock slopes of the LAC are in the range -1 to $-3^{\circ} \mathrm{C}$, which suggests the combined presence of warm and cold permafrost. Warm permafrost is considered here as one whose mean annual temperature is greater than or equal to $-2^{\circ} \mathrm{C}$. It seems indeed that this temperature constitutes a stability threshold both in terms of geotechnical characteristics of the ice (Davies et al. 2001) and stability of high alpine rock slopes (Ravanel et al. 2010a). The threshold between cold and warm permafrost can be placed higher (particularly in soft ground context) or lower (Noetzli et al. 2003) in altitude according to authors.
Surface rock temperature sensors have too recently been implanted at the study area (summer 2011) to directly confirm the TEBAL modelling. However, data of the LAC can be compared - in spite of a difference in altitude of about $150 \mathrm{~m}-$ with those from the Aiguille du Midi boreholes, which are located in rockwalls with aspects close to those of the LAC sensors. At $55 \mathrm{~cm}$ depth, the mean annual temperature of the SE face of the Aiguille du Midi was $0.2^{\circ} \mathrm{C}$ from November 2010 to October 2011; it becomes negative below $1 \mathrm{~m}$, reaching $-1.5^{\circ} \mathrm{C}$ at $10 \mathrm{~m}$ depth; thus, permafrost at this SE face is warm. In the NW face, the mean annual temperature at $55 \mathrm{~cm}$ depth is $-4.2^{\circ} \mathrm{C}$ $\left(-4.7^{\circ} \mathrm{C}\right.$ at $\left.10 \mathrm{~m} \mathrm{depth}\right)$, which indicates cold permafrost. The comparison of data between LAC and Aiguille du Midi during the summer 2011 is presented in Fig. 6. The temperature regime is very similar in the SE faces with a mean offset of nearly $2^{\circ} \mathrm{C}$, which could result from the lower altitude of the LAC sensor, its sheltered position (concave and downwind topography) and the winter and spring snow cover (see Fig. 8b), which prevents the site from intense cooling. Negative mean annual temperatures at the SE aspect are likely found at greater depth $(>1 \mathrm{~m})$ in the LAC compared with the Aiguille du Midi. Rock temperatures in the NW faces of the two sites are very close only after the end of August; before this date, the regularly increasing temperature curve at the Aiguille du Midi is due to the insulating effect of the snow accumulated on the terrace above which the NW borehole is located. The similarity of the NW face 


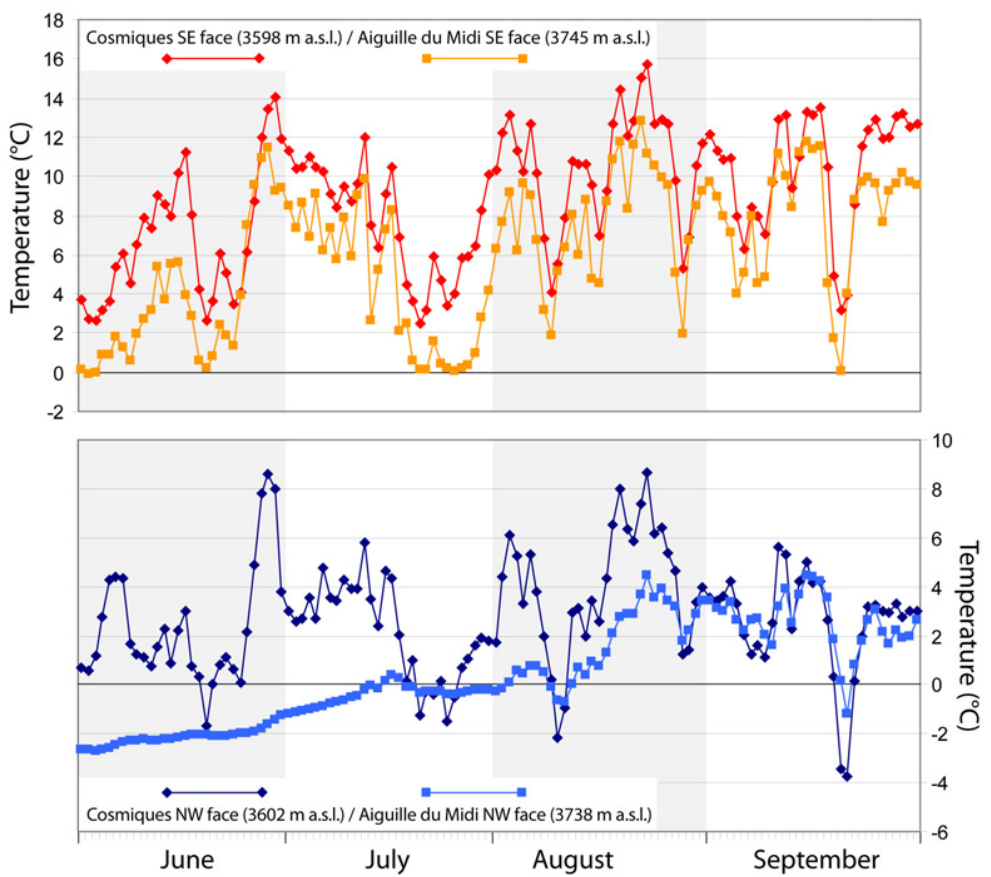

Fig. 6. Rock temperatures measured at 50-55 cm depth at the LAC and the Aiguille du Midi in 2011. Upper panel: SE faces; lower panel: NW faces.

temperatures during the late summer suggests the presence of still cold permafrost on the NW face of the LAC, despite the hot summers of the last two decades. Concerning the active layer at the Aiguille du Midi, it is $1.8 \mathrm{~m}$ and $2.3 \mathrm{~m}$ thick in the NW face, and $5.2 \mathrm{~m}$ and $7.9 \mathrm{~m}$ thick in the SE face in 2010 and 2011 respectively.

The presence of permafrost has been corroborated by the observation of massive ice in several rockfall scars (see Table 1). Only one case of rock particle-free ice was observed, in 2006. Dirty ice could be thick: damage assessors of the 1998 rockfall dug steps in a 20-25 cm thick layer of dirty ice within the scar. These observations emphasize the role of ice in the slope stability.

\section{Surface lowering of the Glacier du Géant}

Glacier evolution is a striking phenomenon in the area of the LAC, as in the whole of the Alps below $4000 \mathrm{~m}$ a.s.l. (Vincent et al. 2005). Mountain guides' experience has shown that loss of ice thickness is not limited to glacier tongues (Fig. 7a) and that many steep mountain flanks have been gradually losing their ice cover (Fig. 8a), even on north faces, which are expected to be colder. Similarly, old IGN topographic maps of 1952 (Fig. 1; scale $1: 10000$ ) or 1972 (scale 1:50 000) represent an almost continuous ice cover on the area at the east and SE of the refuge, which is not the case any longer today. In the study area, couloirs are becoming dry earlier in the year, especially close to rock faces that are increasingly high due to the lowering of the surface of the Glacier du Géant, even if the evolution is not uniform in space and time (Fig. 8) - very snowy winters and cool summers allow the glacier surface to rise again. This evolution is indeed largely dependent on glacial mass balance, whose inter-annual variability is strong (Fig. 7): near the LAC, the eight available annual mass balance measurements over the past 15 years range from $+1.29 \mathrm{~m}(1997-1998)$ to $+3.19 \mathrm{~m}$ water equivalent (1998-1999). In addition to this variability, there is a reduction of the winter and annual mass balance, which explains, together with the submergence velocity, the observed loss of glacier thickness. This loss has been confirmed by the comparison of DEMs extracted from satellite images (Berthier 2005). The data at altitudes over $2500 \mathrm{~m}$ do not permit definitive conclusions as the 

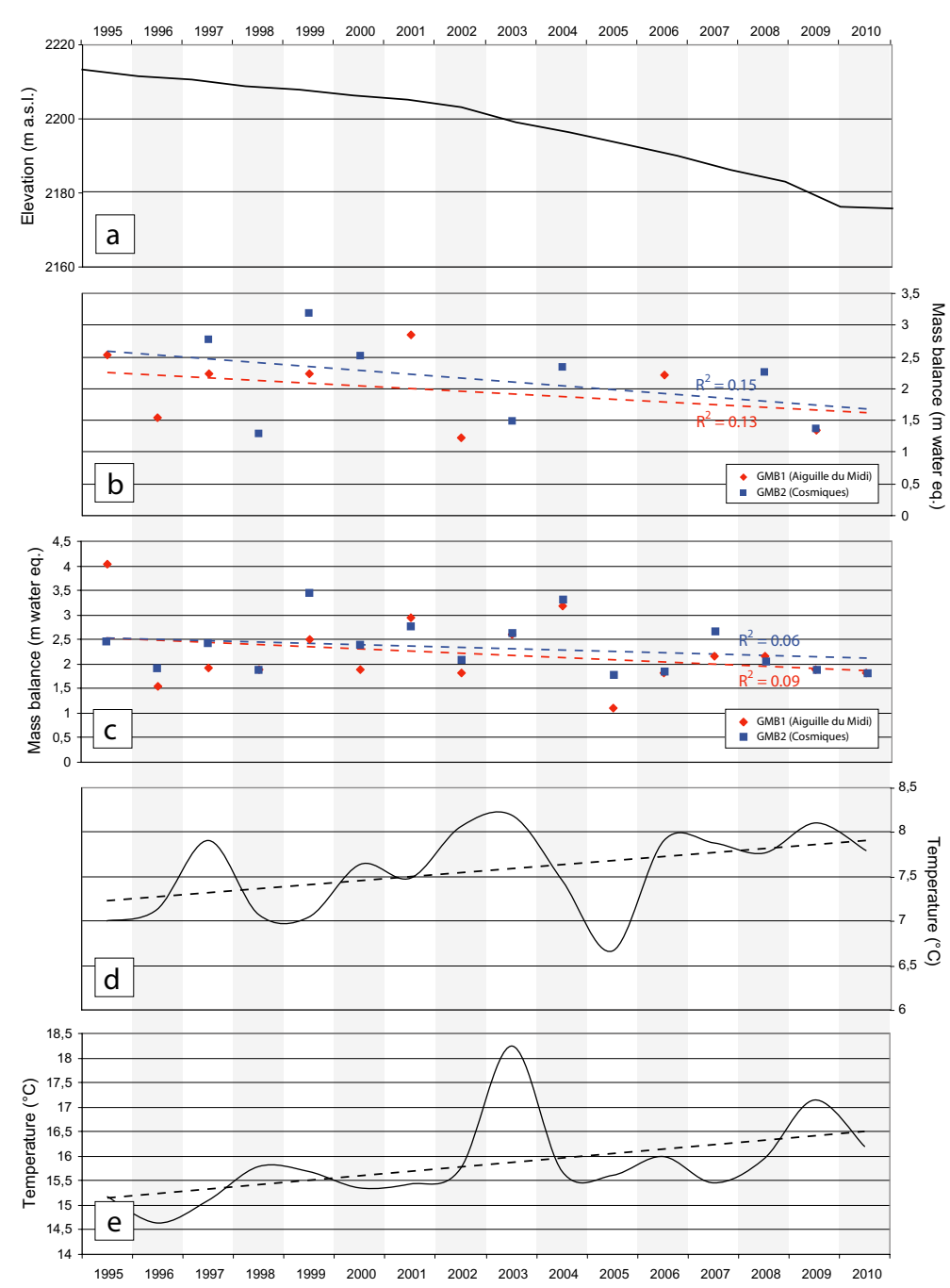

Fig. 7. Elements of evolution of the Mer de Glace basin and temperatures in Chamonix from 1995 to 2010. (a) Evolution of the mean altitude of the cross profile of the Glacier du Tacul; (b) and (c) evolution of the winter and annual Glacier du Géant mass balance, respectively; (d) and (e) changes in annual and summer mean air temperature in Chamonix, respectively (Bouchet station, 1040 m a.s.l.; data: Météo France). Dashed lines: trends (linear regressions).

weak contrast of the images in accumulation areas reduce the accuracy of the DEMs (Berthier et al. 2004). Nevertheless, the map of thickness variations of the Glacier du Géant indicates that in the Col du Midi area (400 m south of the LAC), the ice could have lost more than $40 \mathrm{~m}$ in thickness between 1979 and 2003.

\section{Discussion}

The geological structure of the LAC, with its very fractured or unstructured rock and discontinuities sub-parallel to the slope, appears highly favourable to instabilities. Seismicity as a triggering factor of the rockfalls can be eliminated because none of the precisely dated rockfalls occurred during a significant seismic event (magnitude $\geq 2$ ) registered by the SismAlp network (Thouvenot et al. 1990). The two cryospheric factors, permafrost degradation (Harris et al. 2009) and glacier shrinkage, need therefore to be analyzed (Haeberli 2005; Fischer et al. 2006) in order to understand the recurrent instability of the LAC over the last 15 years, when at least 15 (relatively shallow) 


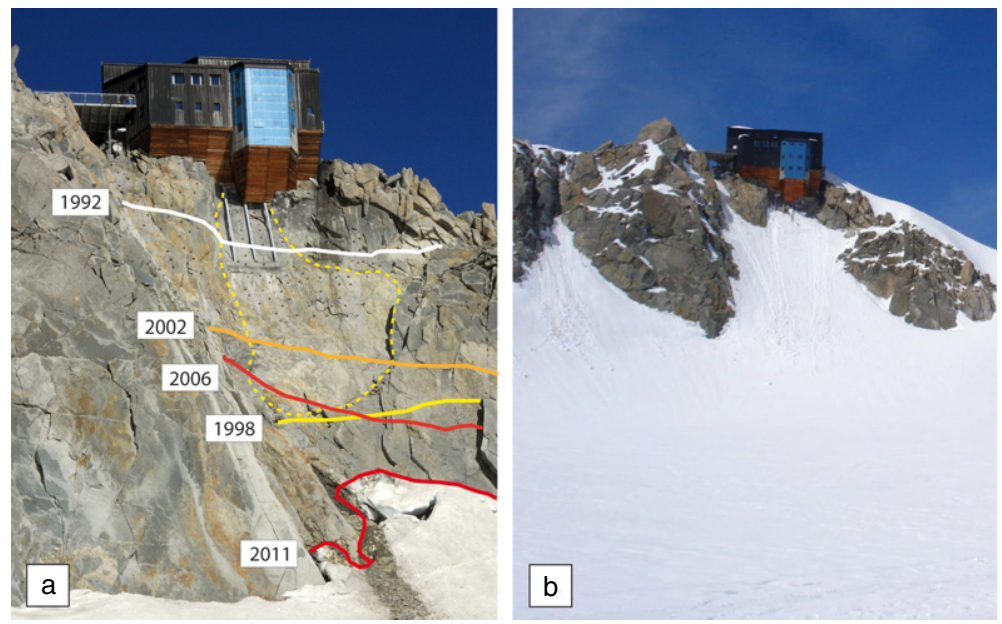

Fig. 8. Evolution of the ice/snow cover below the Refuge des Cosmiques (SE face). (a) Changes in the level of ice documented with photographs taken at the end of summer. Yellow dots: scar of the rockfall of 1998. Altitude changes since 1992: $-21 \mathrm{~m}$ in 1998; $-13.5 \mathrm{~m}$ in $2002 ;-19.5 \mathrm{~m}$ in $2006 ;-25 \mathrm{~m}$ in 2011. Note the steel anchoring and the three IPB which support the 'crystal'. (b) Snow cover can reform temporarily up to the basement of the refuge (photo: 7 May 2008).

rockfalls $\geq 20 \mathrm{~m}^{3}$ occurred, especially on the $\mathrm{SE}$ face.

\section{The role of permafrost}

As suggested by the occurrence of rockfalls mainly during or at the end of hot periods in summer, degradation of the ice has likely participated in the triggering of a large part of these rockfalls. Geotechnical properties of bedrock containing ice depend on temperature (Davies et al. 2001; Gruber and Haeberli 2007): when it increases, the shear strength decreases. As illustrated by the 1998 rockfall, it may trigger mass movements and damage the basements of buildings. The rock temperature increase can be caused either by heat conduction, heat advection or a combination of both (Hasler et al. 2011). In the latter case, it is often the water from snowmelt or storm rainfall that transfers heat to depth, as efficiently as the rock is fractured. The strength of ice depends at the same time on its temperature, hydrostatic pressure, and conditions of its formation, but also depends on the rock materials it contains: dirty ice observed at the LAC is probably of poor geotechnical quality.

The sharp temperature difference that exists between the NW face of the LAC in cold permafrost and the SE face in warm permafrost likely creates a strongly negative horizontal gradient directed from the warmer to the colder side of the ridge. As shown by Noetzli et al. (2007), rock tem- perature fields below high mountain topography are indeed mainly controlled by spatially varying surface temperatures between different sides, with nearly vertical isotherms. As a result of this gradient and the suction force that appears during the formation of ice, pore water can migrate from nonfrozen or thawing areas to frozen areas. Depending on the supply of water, ice lenses can form as a result of this segregation and lead to an expansion of the rock discontinuities (Hasler et al. 2012). Segregation could partly explain the considerable thickness of ice often present in scars on rock mass sliding planes located $1-3 \mathrm{~m}$ in depth. Thus, alternation of increase in ice content during segregation and decrease during the summer period modifies the geotechnical properties of the rock masses, especially in the case of the LAC where rockfalls seem to be primarily related to active layer developments.

At last, an important influence on rock temperature in the LAC could be the influence of the refuge itself on rock temperature. Heat was generated during construction but also during the subsequent use of the refuge. During construction, a disturbance should have occurred through excavation and concrete settings. The excavation created new topographical conditions, generating there the formation of a previously improbable active layer. The formation of this active layer has likely been greatly accelerated in 1989 by the setting of the few dozen of cubic metres of concrete, since concrete 
releases a considerable amount of hydration heat during its setting. According to Bommer et al. (2010), $1 \mathrm{~m}^{3}$ of concrete releases up to $170000 \mathrm{~kJ}$. Due to the lack of precise data, it is difficult to know the amount of heat potentially transmitted to the rock but it is probably high, whereas we do not know if cement was used to fill fractures. In any case, no special technical solution was used to prevent/delay heat transfer into the rock during the construction and during the 1998-1999 work. Currently, and for over 20 years, the refuge is heated 8 months a year, which may locally contribute to the degradation of permafrost. While it does not seem to be major, this factor cannot be totally ruled out to explain the rockfall that occurred just below the refuge in 1998.

\section{The role of glacier retreat}

The evolution of the glacier also directly interferes with the stability of the SE face of the LAC. It is indeed striking to note that the rockfall of 1998 has affected a slab whose base was located under the ice until that year (Fig. 8a). The glacier mass balance of the hydrological year 1997-1998 is the lowest of the 8 years that have been measured, which caused a strong lowering of the glacier and the snow cover below the refuge. Similarly, 2010 and 2011 rockfalls in the couloir located east of the refuge were possibly related to the lowering of the glacier in the recent years. Before these dates, the glacier exerted a buttressing effect, stabilizing the critical geological structure. This is corroborated by the two rockfalls that occurred at the foot of the Cosmiques spur (250 m north of the refuge) between 2010 and 2011. Besides, the mean date of the rockfalls which occurred at the foot of the rock slope is found more than 22 days after the mean date of the events, which occurred in the crest area (Fig. 9): collapses due to the decrease of the glacier may occur later than those associated with the permafrost activity/degradation. The glacier and its minimum level take place a bit later than the maximum activity in the active layer causing destabilization.

\section{Concluding remarks}

A large number of the rockfalls which have affected the LAC over the last 15 years seem to result from permafrost activity/degradation and loss of glacier buttressing or from their combination. Given the presence of permafrost and the

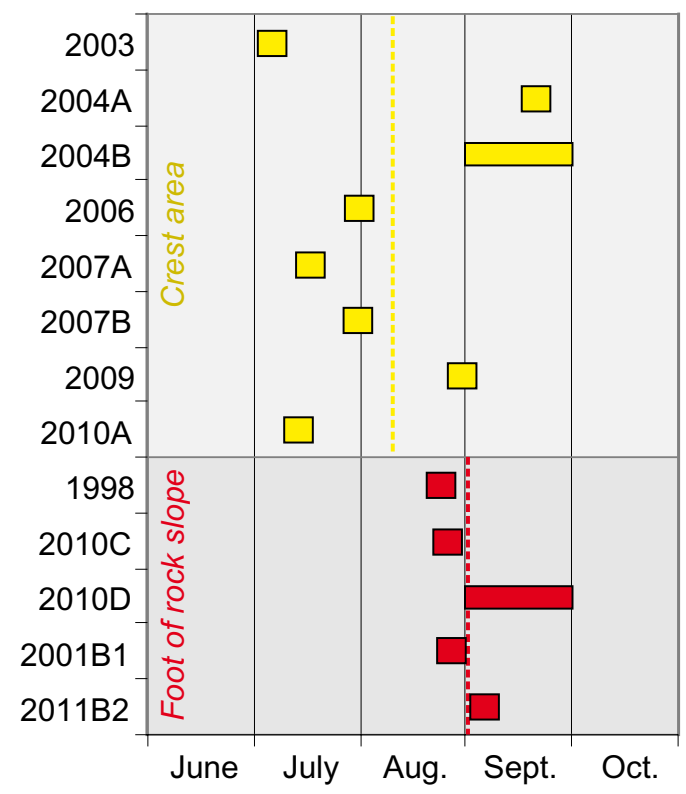

Fig. 9. Timing of the precisely dated rockfalls $\geq 20 \mathrm{~m}^{3}$ of the SE face of the LAC. Dashed lines: means.

proximity of the Glacier du Géant, the LAC should have benefitted from a detailed preliminary study before the construction of the refuge. It should have prepared an in-depth analysis of the glacier, rock temperature, and ice content, and analysed the geological and geomorphological context in order to forecast changes in the permafrost and glacier, and to determine long-term geotechnical characteristics of the bedrock during the lifetime of an infrastructure located in a high mountain area especially as some guides who participated in the construction argue that the presence of the ice behind the collapsed slab of 1998 was known during the construction of the refuge. In-depth analysis should now be a precondition to any construction in high mountain areas in the current context of global warming to identify the risks and the requisite engineering actions to ensure safety of structures and people and avoid costly work in case of instability.

\section{Acknowledgements}

We thank L. Cantèle and A. Sage, the two keepers of the Refuge des Cosmiques, and alpine guides of the Compagnie des Guides de Chamonix for all the information given. Rock temperatures at the LAC were obtained using thermistors developed and 
handled by U. Morra di Cella and P. Pogliotti (ARPA Valley of Aosta). MAGST was modelled by S. Gruber (University of Zurich). The reviewers M. Phillips and W. Haeberli are thanked for their constructive remarks on the manuscript.

Ludovic Ravanel, Environnements, Dynamiques et Territoires de la Montagne (EDYTEM Lab.), Université de Savoie, CNRS, F-73376, Le Bourget-du-Lac, France

E-mail: ludovic.ravanel@univ-savoie.fr.

Philip Deline, Environnements, Dynamiques et Territoires de la Montagne (EDYTEM Lab.), Université de Savoie, CNRS, F-73376, Le Bourget-du-Lac, France

E-mail: philip.deline@univ-savoie.fr

Christophe Lambiel, Institut de Géographie de l'Université de Lausanne (IGUL), Université de Lausanne, DorignyAnthropole, CH-1015, Lausanne, Switzerland

E-mail: christophe.lambiel@unil.ch

Christian Vincent, Laboratoire de Glaciologie et Géophysique de l'Environnement (LGGE), Université J. Fourier, CNRS, F-38402, Saint Martin d'Hères, France

E-mail: vincent@1gge.obs.ujf-grenoble.fr

\section{References}

Abellan, A., Jaboyedoff, M., Oppikofer, T. and Vilaplana, J.M., 2009. Detection of millimetric deformation using a terrestrial laser scanner: experiment and application to a rockfall event. Natural Hazards and Earth System Sciences, 9, 365-372.

Arenson, L., Phillips, M. and Springman, S.M., 2009. Geotechnical considerations and technical solutions for infrastructure in mountain permafrost. In: Krugger, M.I. and Stern, H.P. (eds), New Permafrost and Glacier Research, Nova Science Publishers, Inc. 3-50.

Bamber, J.L. and Payne, A.J., 2004. Mass Balance of the Cryosphere: Observations and Modelling of Contemporary and Future Changes. Cambridge University Press, Cambridge.

Berthier, E., 2005. Dynamique et bilan de masse des glaciers de montagne (Alpes, Islande, Himalaya): contribution de l'imagerie satellitaire. $\mathrm{PhD}$ thesis, University of Toulouse III, Toulouse, France.

Berthier, E., Arnaud, Y., Baratoux, D., Vincent, C. and Rémy, F., 2004. Recent rapid thinning of the Mer de Glace glacier derived from satellite optical images. Geophysical Research Letters, 31, L17401.

Bommer, C., Phillips, M. and Arenson, L.U., 2010. Practical recommendations for planning, constructing and maintaining infrastructure in moutain permafrost. Permafrost and Periglacial Processes, 21, 97-104.

Cossart, E., Braucher, R., Fort, M., Bourlès, D.L. and Carcaillet, J., 2008. Slope instability in relation to glacial debuttressing in alpine areas (Upper Durance catchment, south-eastern France): evidence from field data and $10 \mathrm{Be}$ cosmic ray exposure ages. Geomorphology, 95, 3-26.
Davies, M.C.R., Hamza, O., Lumsden, B.W. and Harris, C., 2000. Laboratory measurements of the shear strength of ice-filled rock joints. Annals of Glaciology, 31, 463467.

Davies, M.C.R., Hamza, O. and Harris, C., 2001. The effect of rise in mean annual temperature on the stability of rock slopes containing ice-filled discontinuities. Permafrost and Periglacial Processes, 12, 137-144.

Fischer, L., Kääb, A., Huggel, C. and Noetzli, J., 2006. Geology, glacier retreat and permafrost degradation as controlling factors of slope instabilities in a highmountain rock wall: the Monte Rosa east face. Natural Hazards and Earth System Science, 6, 761-772.

Gruber, S. and Haeberli, W., 2007. Permafrost in steep bedrock slopes and its temperature-related destabilization following climate change. Journal of Geophysical Research, 112, F02S18.

Gruber, S., Hoelzle, M. and Haeberli, W., 2004. Rock-wall temperature in the Alps: modelling their topographic distribution and regional differences. Permafrost and Periglacial Processes, 15, 299-307.

Haeberli, W., 1992. Construction, environmental problems and natural hazards in periglacial mountain belts. Permafrost and Periglacial Processes, 3, 111-124.

Haeberli, W., 2005. Investigating glacier-permafrost relationships in high-mountain areas: historical background, selected examples and research needs. In: Harris, C. and Murton, J.B. (eds), Cryospheric Systems: Glaciers and Permafrost. Geological Society, London. Special publication, 242, 29-37.

Haeberli, W., Wegmann, M. and Vonder Mühll, D., 1997. Slope stability problems related to glacier shrinkage and permafrost degradation in the Alps. Eclogae Geologicae Helvetiae, 90, 407-414.

Harris, C., Arenson, L.U., Christiansen, H.H., Etzelmüller, B., Frauenfelder, R., Gruber, S., Haeberli, W., Hauck, C., Hölzle, M., Humlum, O., Isaksen, K., Kääb, A., KernLütschg, M.A., Lehning, M., Matsuoka, N., Murton, J., Nötzli, J., Phillips, M., Ross, N., Seppälä, M., Springman, S.M. and Vonder Mühll, D., 2009. Permafrost and climate in Europe: monitoring and modelling thermal, geomorphological and geotechnical responses. EarthScience Reviews, 92, 117-171.

Harris, C., Davies, M.C.R. and Etzelmüller, B., 2001. The assessment of potential geotechnical hazards associated with mountain permafrost in a warming global climate. Permafrost and Periglacial Processes, 12, 145156.

Hasler, A., Gruber, S. and Beutel, J., 2012. Kinematics of steep bedrock permafrost. Journal of Geophysical Research. doi:10.1029/2011JF001981.

Hasler, A., Gruber, S., Font, M. and Dubois, A., 2011. Advective heat transport in frozen ground clefts. Permafrost and Periglacial Processes, 22, 378-389.

Kenner, R., Phillips, M., Danioth, C., Denier, C., Thee, P. and Zgraggen, A., 2011. Investigation of rock and ice loss in a recently deglaciated mountain rock wall using terrestrial laser scanning: Gemsstock, Swiss Alps. Cold Regions Science and Technology, 67, 157-164.

Krautblatter, M., 2009. Detection and quantification of permafrost change in alpine rock walls and implications for rock instability. $\mathrm{PhD}$ thesis, University of Bonn, Bonn, Germany. 
Lichti, D.D., Gordon, S.J. and Stewart, M.P., 2002. Groundbased laser scanners: operations, systems and applications. Geomatica, 56, 21-33.

Noetzli, J., Gruber, S., Kohl, T., Salzmann, N. and Haeberli, W., 2007. Three-dimensional distribution and evolution of permafrost temperatures in idealized high-mountain topography. Journal of Geophysical Research, 112, F02S13.

Noetzli, J., Hoelzle, M. and Haeberli, W., 2003. Mountain permafrost and recent Alpine rock-fall events: a GISbased approach to determine critical factors. In: Philipps, M., Springman, S. and Arenson, L. (eds), Proceedings of the 8th International Conference on Permafrost, Zürich, Switzerland, Swets \& Zeitlinger, Lisse, 827-832.

Oppikofer, T., Jaboyedoff, M. and Keusen H.R., 2008. Collapse at the eastern Eiger flank in the Swiss Alps. Nature Geoscience, 1, 531-535.

Paul, F. and Haeberli, W., 2008. Spatial variability of glacier elevation changes in the Swiss Alps obtained from two digital elevation models. Geophysical Research Letters, 35, L21502.

Rabatel, A., Deline, P., Jaillet, S. and Ravanel, L., 2008. Rock falls in high-alpine rock walls quantified by terrestrial LiDAR measurements: a case study in the Mont-Blanc area. Geophysical Research Letters, 35, L10502.

Ravanel, L., Allignol, F., Deline, P., Gruber, S. and Ravello, M., 2010a. Rockfalls in the Mont Blanc massif in 2007 and 2008. Landslides, 7, 493-501.

Ravanel, L., Deline, P. and Jaillet, S., 2010b. Quantification des éboulements/écroulements dans les parois de la haute montagne alpine: quatre années de laserscanning terrestre dans le massif du Mont-Blanc. Revue Française de Photogrammétrie et de Télédétection, 192, $58-65$.

Thouvenot, F., Fréchet, J., Guyoton, F., Guiguet, R. and Jenatton, L., 1990. SismAlp: an automatic phoneinterrogated seismic network for the western Alps. Cahiers du Centre Européen de Géodynamique et de Sismologie, 1, 1-10.

Vincent, C., Le Meur, E., Six, D. and Funk, M., 2005. Solving the paradox of the end of the Little Ice Age in the Alps. Geophysical Research Letters, 32, L09706.

Manuscript Received 15 Nov., 2011, revised and accepted 30 Jul., 2012 